\title{
Changes in Knowledge Management Strategies Can Support Emerging Innovative Actors in Organic Agriculture: The Case of Participatory Plant Breeding in Europe
}

\author{
Livia Ortolani ${ }^{1,2, *}$, Riccardo Bocci ${ }^{2}$, Paolo Bàrberi ${ }^{3}$, Sally Howlett ${ }^{4}$ and Véronique Chable ${ }^{5}$ \\ ${ }^{1}$ Interdepartmental Centre for Agro-environmental Research "Enrico Avanzi”, San Piero a Grado, Italy \\ ${ }^{2}$ Associazione Italiana per l'Agricoltura Biologica, Rome, Italy \\ ${ }^{3}$ Institute of Life Sciences, Scuola Superiore Sant'Anna, Pisa, Italy \\ ${ }^{4}$ Organic Research Centre, Hamstead Marshall, UK \\ ${ }^{5}$ INRA Centre Rennes-Le Rheu, Le Rheu, France \\ * Corresponding author: E-Mail: liviaortolani@gmail.com, Tel.: +39 3334830000, Fax: +39 645437469
}

Submitted: 16 May 2016 | In revised form: 19 October 2016 | Accepted: 28 December 2016 |

Published: 5 May 2017

\begin{abstract}
The "transfer of technology", typical of a top-down linear process of innovation cannot be used in the new contexts of sustainability, characterised by uncertainty and complexity. There is a need to redefine categories and concepts around which innovation and agricultural policies are built, as those currently in use provide only a partial representation of reality. Innovation paradigms underpinning technological development and public policies design will have a direct impact on decisions regarding which agricultural models will ultimately be supported. Looking at local learning capacity and systems of relations can help to understand the potential to develop innovation within a specific context. This work contributes to the definition of new actors who are developing innovation for sustainability in rural areas. The study focuses on the knowledge systems of farmers who are applying alternative breeding strategies: it uses a network approach to explore the knowledge system in which individual farmers are embedded in order to understand their specific relational features. Three main conclusions emerge from the study: for enhancing the agro-ecological innovation paradigm there is a need to define the 'innovation broker', to revise the evaluation system of public research and to integrate innovation and agricultural policies.
\end{abstract}

Keywords: innovation paradigms; network analysis; advisory services; research evaluation

1. Introduction: Emerging Innovative Actors in Agriculture

Various agricultural models exist in the global context, with family or peasant agriculture and industrial/corporate farming at opposing ends of the spectrum. Van der Ploeg [1] underlines how a peasant-farming model based on di- rect management of resources, struggle for autonomy and cooperation among rural actors is achieving success as a response to the economic, social, food and ecological crisis [2]. Based on intense knowledge exchange activities, such models would seek to establish fresh niches of autonomy within a broader economic context characterized by farmers' independence from external actors 
and marginalisation by the demand of the global market. Several actors are experimenting with such organizational models at a local level and supporting them would enable the realization of this transition. Rural sociological studies of the last two decades have reviewed such scenarios; however, current agricultural policies often do not meet needs of these actors [3]. Likewise, characterising the peasants as not yet possessing entrepreneurial skills or as a disappearing group is clearly deficient [1]. There is a need to redefine the categories and concepts around which agricultural policies are built, as those currently in use provide only a partial representation of reality.

The aim of this work is to contribute to the definition of new actors who are developing innovation for sustainability in rural areas, with a focus on the knowledge systems in which they are embedded. Innovation paradigms underpinning technological development and public policies have a direct impact on decisions regarding which agricultural models will ultimately be supported. This process is particularly evident in plant breeding. Conventional plant breeding strategies aimed at high crop yields and high technological quality through uniformity and wide adaptation, are partially responsible for the increased erosion of agricultural diversity [4] and for the abandonment of marginal agricultural areas such as mountainous and hilly land $[5,6]$. However, today such areas are frequently those where new innovative actors are developing their activities and where alternative breeding strategies are elaborated and tested.

This paper will focus on the study of knowledge systems of individual farmers applying crop breeding strategies based on local adaptation through decentralisation and participation. It uses a network approach to explore the knowledge systems in which farmers are embedded in order to understand their specific relational characteristics. Networks of four organic farmers are used as case studies. The first two sections will describe emerging divergent agricultural innovation paradigms in Europe, with a focus on knowledge management and plant breeding. The second section will present the analysis of the four innovative organic farmers knowledge networks developed within the framework of the European Framework Programme 7 research project, SOLIBAM. The structure and actors included in the knowledge networks of the four case studies will be illustrated and discussed. Finally, some policy recommendations on how agricultural research systems can support emerging innovative actors will conclude the paper.

\section{How Innovation Paradigms Influence the Transition Towards Sustainability}

System innovations are multi-factor, multi-actor and multi-level processes [7]. Different innovation paradigms result in different roadmaps and models towards the future of agriculture. The idea of sustainability as a normative notion that should assure justice among humans of present and future generations and among humans and nature $[8,9]$ has several interpretations depending on the scientific ap- proach used. Furthermore, the main paradigm chosen to underpin research policies has a direct influence on the direction of society's transition to sustainability. The Knowledge Based Bio Economy (KBBE) innovation paradigm, which predominates in the EU, strongly relies on technical innovation developed through the life sciences, following a reductionist approach and strong scientific specialisation. The analysis of behavioural and institutional changes is not directly included in the associated innovation process as it is delegated to other scientific disciplines [7]. The KBBE approach in agricultural research focuses mainly on the maximisation of productivity and economic efficiency on a global level. It could lead to incremental system changes that may support the transition to sustainability, but it could also potentially turn agriculture into a factory-like production system [7], reducing the importance of local and traditional knowledge systems $[10,11]$. There is a need, therefore, to take into account the long-term effects that any single specific innovation could generate. Following a vision of integral sustainability, innovation in agriculture should work to build new relationships between local actors, communities and their natural contexts $[12,13]$. Sustainability becomes a question of governance and the role of communities and the promotion of social and institutional learning for sustainable development become key elements of sustainability science [14]. Social innovation is needed as much as technological innovation based on life science to reach the sustainability goals. "Agroecology" $[15,16]$ represents an innovation paradigm that is gaining importance in Europe as complementary to that of the KBBE in agricultural sciences. According to this paradigm agricultural systems are designed in such a way as to minimize the need for external inputs and improve reliance on ecological interactions [8]. The original notion of organic agriculture is one basis upon which to conceptualise this paradigm. Following this approach, one of the main requirements for sustainability is to base food production within agroecological settings [17].

\section{Plant Breeding as an Example of Knowledge Management in Two Agricultural Innovation Paradigms}

In the KBBE paradigm, innovation is a research-driven process based on scientific knowledge and promoted by intellectual property rights, where specific policies are defined in retrospect for dissemination of science and innovation transfer [18] following a linear model of innovation $[19,20]$. According to the agroecological vision, research and innovation policies should promote the combination of different types of knowledge (scientific, lay, tacit, local) and worlds (science, production, consumption, etc.) in a process of mutual learning, with the aim of finding practical solutions for complex problems [21]. Here, the associated knowledge management model is that of Agricultural Knowledge and Innovation Systems (AKIS), which considers innovation as a process of networking and iterative learning among a heterogeneous set of actors $[22,23]$. 
The KBBE model leads to expert-dominated discourses that need specific policies in order to be applied by end users. However, fixed rules and thresholds based on scientific evidence, (e.g. tools for sustainability assessment based on linear optimization models; command and control policies based on pesticide residues etc.) are more likely to hinder rather than to promote rural development, excluding rural actors and their (local, tacit) knowledge from the transition to sustainability [24]. In contrast, in the AKIS model the involvement of a variety of stakeholders in the development of innovation and research is the key to finding a suitable solution for each specific context.

Plant breeding strategies permit the identification of the knowledge management approach to which a specific farmer or researcher refers, and, as a consequence, the agricultural innovation paradigm associated with it. In the KBBE paradigm, breeding is mainly a tool to increase productivity or achieve other objectives through genetic uniformity. It is based on the idea of wide adaptation of varieties i.e. the same variety should be cultivated across as large an area as possible in order to recover the cost of research and development [25]. In the agroecological innovation paradigm and, in particular, in the research developed for organic farming, local adaptation through genetic diversity is one of the main drivers of innovation $[8,26]$. Crop breeding for organic agriculture is a good example to illustrate how a better understanding of technological changes should be integrated with changes in rules, behaviours of individual stakeholders, culture, institutions and science. Organic agriculture requires crop varieties adapted to different agricultural, environmental, cultural and social contexts, avoiding the need for external inputs and increasing the ecological interactions among biological components to stimulate the internal potential for soil fertility building, productivity and crop protection [27]. However, commercially available crop varieties, even if certified organic, are characterised by genetic uniformity and are mostly selected under conventional farming conditions, which traditionally use high-energy inputs such as chemicals for fertilization and plant protection. The use of such varieties in organic agriculture promotes an input substitution approach increasing the risk for conventionalisation [28]. The diffusion of selection processes across different environmental conditions incorporating the direct involvement of farmers has great potential to develop crop varieties better adapted to different organic and low input farming systems [29]. Decentralized and Participatory Plant Breeding (PPB) is a promising approach for developing innovation in plant breeding following the agroecological paradigm. PPB has been carried out traditionally with small farmers in developing countries $[25,30,31]$. More recently it has been proposed as an alternative breeding approach for organic and low input farming in Europe [32] with a focus on adaptation to climate change [29]. PPB is often criticized for the high investment in time and resources required to build farmer networks, but in a context where farmers are already embedded in social networks such investments can be significantly lower and may not entail additional efforts for dissemination or marketing of the varieties released [33]. We used the plant breeding approach to identify farmers that are following the agroecological innovation paradigm. To understand how to support the development of this emerging approach to innovation as complementary to the dominant one, we studied the knowledge management networks of farmers involved in Participatory Plant Breeding in Europe.

\section{Analysis of Farmers' Knowledge Networks}

Network analysis [34-38] has great potential to describe complex farm systems that aim to integrate the goal of productivity with those of autonomy, stability, diversity and quality. Farmers are moving in complex environments with several economic, environmental, social and cultural factors influencing their behaviour and they often tend to see their practices and the reasons they use them in terms of social relationships [39]. Van der Ploeg [1] used the term "autonomy" to refer to the need of individual farmers to reduce their dependency on external inputs and market prices. In this view, the new peasant needs to work hard on developing synergies with ecological processes and social connections. The analysis of social connections that influence knowledge management was conducted on four case studies of farmers involved in PPB experiments in the framework of the SOLIBAM project. The strategies of SOLIBAM focus on the integration of breeding approaches (such as Evolutionary or Participatory Plant Breeding, increasing stability through genetic diversity and the development of organic wheat varieties) with agronomic methods of farm management (such as intercropping and associated crops). They represent an example of technologies that promote farmers' interactions with nature [40].

\subsection{Research Methodology}

As the aim of this study was to contribute to the description of emerging innovative actors in organic agriculture with a focus on knowledge management strategies, we selected organic farmers involved in PPB experiments in Europe. In particular we identified four case studies of farmers that local researchers and stakeholders recognise as examples of best practice of innovative organic farmers in their region. Four organic farmers in France and Italy were studied in terms of the actors involved in their knowledge system and their respective roles. A description of the farms is given in Table 1. The focus was on person-based processes that influence the decision making of individual agricultural stakeholders [41]. The four farmers were interviewed regarding their innovation strategies, being asked to describe the actors involved in their knowledge network. A participatory approach for data collection, known as Participatory Mapping [42], was used with the aim of improving the data collection procedure for personal networks in rural contexts. Using this approach, farmers were directly involved in defining their 'relationship maps' through a facilitated workshop with researchers. The result was a directed graph (i.e. a network of nodes and 
directed arrows) showing the relationships that directly and indirectly influence the functioning of the farm.

The visualisation of the relationship map helps farmers to give more information about the connections between actors than the use of a questionnaire. The researcher firstly asked the farmer to identify actors influencing his innovation strategy and then to show the connections between actors by asking: who are the actors you exchange knowledge with? [38]. This process allowed a large amount of data to be collected in a short time and resulted in being a particularly suitable approach to describe innovative agricultural models through their knowledge systems. The mapping approach allowed the respondents to visualize their relational systems while describing it verbally to the researcher, increasing the potential of network analysis as an awareness-building tool [43].

Table 1. Main features of the four case study farms.

\begin{tabular}{|c|c|c|c|c|}
\hline & IT1 & IT2 & FR1 & FR2 \\
\hline Location & Tuscany & Friuli & Brittany & Brittany \\
\hline $\mathrm{Ha}$ & 300 & 21 & 70 & 8 \\
\hline Workers & 9 & 1 & 2 & 1 (3h/week) \\
\hline Household & 3 people & 2 people & 4 people & 4 people \\
\hline $\begin{array}{l}\text { Total revenue } \\
(2010)\end{array}$ & $\begin{array}{l}\text { Between } 150.000 \\
\text { and } 200.000\end{array}$ & $\begin{array}{l}\text { Between } 100.000 \\
\text { and } 150.000\end{array}$ & $\begin{array}{l}\text { Between } 150.000 \\
\text { and } 200.000\end{array}$ & $\begin{array}{l}\text { Between } 25.000 \text { and } \\
30.000\end{array}$ \\
\hline Organic/mix & Organic since 1987 & Mix, 6 ha organic & Organic since 1985 & $\begin{array}{l}\text { Organic since the } \\
\text { start up phase }\end{array}$ \\
\hline Main crops & $\begin{array}{l}\text { Arable crops: cereals, } \\
\text { legume crops. }\end{array}$ & $\begin{array}{l}\text { Vegetables (6 ha } \\
\text { organic), Arable } \\
\text { crops: cereals } \\
\text { (conventional) }\end{array}$ & $\begin{array}{l}\text { Livestock (cows, } \\
\text { chicken, pigs) and } \\
\text { arable crops: } \\
\text { cereals. }\end{array}$ & $\begin{array}{l}\text { Cereals, vegetables, } \\
\text { fruits, livestock } \\
\text { (rabbit, chickens) }\end{array}$ \\
\hline Products & Bread and pasta & $\begin{array}{l}\text { Vegetables and } \\
\text { cereals }\end{array}$ & $\begin{array}{l}\text { Cheese, butter, } \\
\text { yogurt, cereals and } \\
\text { flour }\end{array}$ & $\begin{array}{l}\text { Bread, gallettes, } \\
\text { meat, apple juice, } \\
\text { cider }\end{array}$ \\
\hline Supply Chain & $\begin{array}{l}\text { Food processing and } \\
\text { on farm sale of bread } \\
\text { and pasta }\end{array}$ & $\begin{array}{l}\text { Fresh vegetables for } \\
\text { direct selling and raw } \\
\text { cereals for } \\
\text { processing }\end{array}$ & $\begin{array}{l}\text { Food processing on } \\
\text { farm for dairy } \\
\text { products and flour } \\
\text { production }\end{array}$ & $\begin{array}{l}\text { Food processing on } \\
\text { farm for bread and } \\
\text { gallettes } \\
\text { (paysan-boulanger) }\end{array}$ \\
\hline Seeds/breeding & $\begin{array}{l}\text { Old varieties since } \\
2006 \text {. Home saved } \\
\text { and reproduced in a } \\
\text { network of farms }\end{array}$ & $\begin{array}{l}\text { Home saved, } \\
\text { reproduced on farm. }\end{array}$ & $\begin{array}{l}\text { Home saved, } \\
\text { agrobiodiversity, } \\
\text { seed exchange, on } \\
\text { farm selection }\end{array}$ & $\begin{array}{l}\text { Home saved, } \\
\text { reproduced on farm }\end{array}$ \\
\hline Innovations & $\begin{array}{l}\text { Conversion to } \\
\text { organic farming- } \\
\text { Introduction of old } \\
\text { cereal varieties in the } \\
\text { fields - Processing } \\
\text { plants for old cereal } \\
\text { varieties. }\end{array}$ & $\begin{array}{l}\text { Modification of the } \\
\text { farm organizational } \\
\text { model - Crop } \\
\text { diversification - } \\
\text { Reduction of } \\
\text { cultivated land. }\end{array}$ & $\begin{array}{l}\text { Swiss cow landrace, } \\
\text { cereal selection for } \\
\text { hay to feed animals - } \\
\text { Cereal selection for } \\
\text { high quality bread } \\
\text { and flour production - } \\
\text { On farm conservation } \\
\text { of old varieties }\end{array}$ & $\begin{array}{l}\text { Use of animal labour } \\
\text { in the field }(60 \%) \text { - } \\
\text { Bread making } \\
\text { strategies - Bread } \\
\text { home delivery. }\end{array}$ \\
\hline Funds & EU RDP & EU CAP & $\begin{array}{l}\text { Research projects } \\
\text { (EU, private } \\
\text { foundations etc.) }\end{array}$ & EU CAP \\
\hline Market channels & $\begin{array}{l}\text { On farm shop, } \\
\text { e-commerce, } \\
\text { consumers groups, } \\
\text { local shops and } \\
\text { restaurants. }\end{array}$ & $\begin{array}{l}\text { Farmer's markets } \\
\text { and consumers' } \\
\text { groups for } \\
\text { vegetables. Large } \\
\text { distribution for } \\
\text { cereals }\end{array}$ & $\begin{array}{l}\text { Farmers'markets, on } \\
\text { farm shop, } \\
\text { consumers'groups, } \\
\text { local bakeries and } \\
\text { shops. }\end{array}$ & $\begin{array}{l}\text { Consumers'groups, } \\
\text { on farm shop shared } \\
\text { with other farmers, } \\
\text { bread home delivery, } \\
\text { local shops. }\end{array}$ \\
\hline
\end{tabular}




\subsection{Results}

The selected farmers have a vision of agriculture as an activity that goes beyond simply food production, embedding the development of social relationships in the production process [41]. This vision is communicated through direct contact: the possibility to buy the products directly on farm guarantees a continuous exchange of knowledge between the farmer and the consumers. This exchange is deeper when other activities with consumers, such as voluntary work and on-farm visits, bring people with different backgrounds to the farm. The public research institutions contribute to the farmer's innovation development with scientific knowledge that responds to the consumers demand for sustainable production. These farmers represent practices at a local level that can become a point of reference for other local actors interested in organic and low input farming. If this approach to agriculture meets a local and regional context in which substantial changes among various stakeholder groups have taken place simultaneously, there is a high possibility for the local system to improve sustainability as a governance process. Moreover, they have a large potential in improving local sustainability thanks to their capacity to connect with other producers, rural stakeholders and wider society actors.

The choice to be organic and to follow values and principles of the original organic vision coincides with their choice to be farmers. It represents a baseline in their process of developing innovative organisational models. The farmers interviewed have quite different backgrounds. The French farmers are part of the stream of people who, in the 1970s and again in recent years, started moving back to the land as an alternative to urban industrial life. FR1 is a second generation organic farmer who wants to improve their parents' decision, while FR2 started farming ten years ago. Also ten years ago, FR1 started to experiment with cereal selection on an organic dairy farm, while FR2 bakes bread on farm and sells it to local consumers. The Italian farmers come from traditional agricultural families; both of them made the choice to change their farm structure and organisation with the aim of keeping agriculture as the main income for the family. IT1 invested in the cultivation of local and old varieties of cereals and processing the grain to produce bread and pasta. IT2 focused on reducing costs, reducing farm size and introducing vegetable production with high agrobiodiversity.

Figure 1 shows the knowledge network of the four farmers, using different colours for the economic sector of the actors involved and different node dimensions for the relevance of each actor in terms of the number of connections. FR2 and IT2 tend to have a strong role of the farmer in the knowledge networks, as they are the only nodes of a large size and all knowledge exchange flows pass by the farmer. FR1 and IT1 have a more polycentric network, where other actors, e.g. members of the farmer family or technicians working in collaboration with the farmers, have a significant role in managing the knowledge exchange process.

Networking is an important aspect in the development of a new farm or an innovative approach to farming. FR2 and IT2 had to create relationships with local actors over time that they directly manage. Both FR2 and IT2 are the main individuals responsible for the farm activity and the ones who make choices every day. The role of the workers is secondary in this type of farm due to the specific organisational model based on family work, and also to the small size of the farms ( 3 to 6 ha). Most of the actors in these farmers' networks are individuals; a direct connection with collective actors that would have a potential to enlarge their network is missing. FR2 listed 28 actors while IT2 described a total of 20 actors: they are looking at other actors in terms of what they can get from them to improve their system. Most of the actors in the network are directly related to the farmer without any connection to each other. The analysis of the FR2 network allows us to identify the two associated realities in which the farmer is embedded: seed networks and organic agriculture associations (see Appendix for complete list of actors). However, FR2 also described his relationships with individual farmers that are based on personal continuous knowledge exchange with a high level of reciprocity. FR2 nominated five individual farmers and the person who sold him the oven for baking his own bread as people that contribute to his knowledge exchange network on specific problems. The other farmers represent an important source of information on what is going on outside the local area and they can give important insights for the management of the farm. The knowledge network of IT2 focuses on the farmer's direct contacts. The low receptivity of the local context hampers his possibility to share his innovative vision with local actors. However, his breeding experience in horticulture attracted several researchers at national and international level, thanks to the contact with other farmers. This allows IT2 to be involved in research projects and to exchange his seeds with other farmers with similar experiences. The knowledge exchange network of both IT2 and FR2 involves the actors related to market channels such as consumers groups, consumers on farm and farmers markets.

Even if, as part of the farmers' visions, direct contact with consumers should be key to the farm model they want to develop, they have a low capacity to influence this in practice due to the short time the farmers have to spend in the shop talking to consumers. FR1 and IT1 are examples of family farms of a significant size (between 70 and 300 ha) that decided to invest in innovation to maintain farming activity as the main source of income. They have larger knowledge exchange networks than the other farmers observed in this work. Their active participation in research projects and the continuous development of PPB make FR1 and IT1 familiar with the mutual learning process between farmers and researchers. 
a)

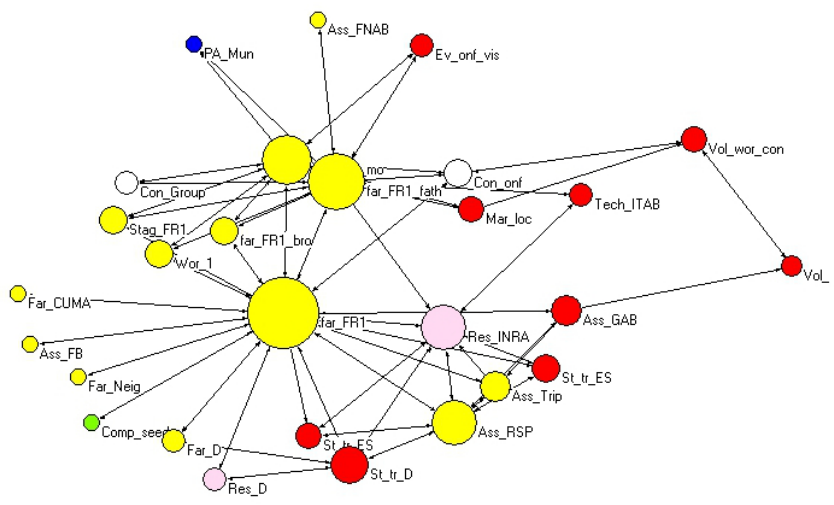

c)

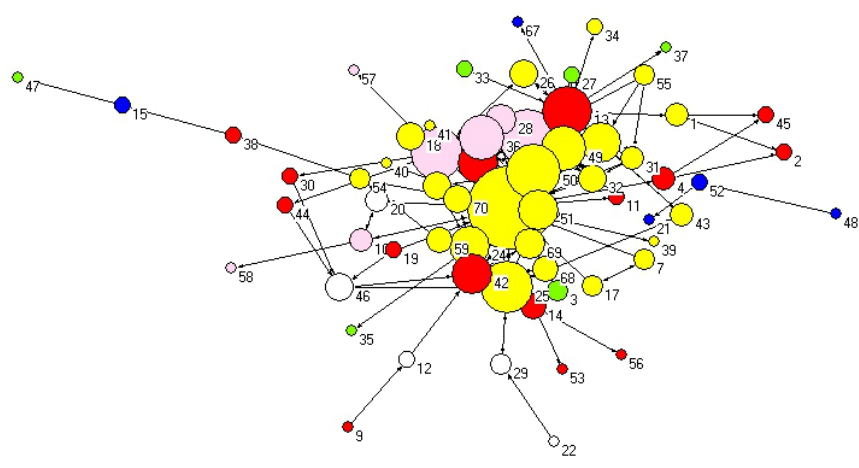

b)

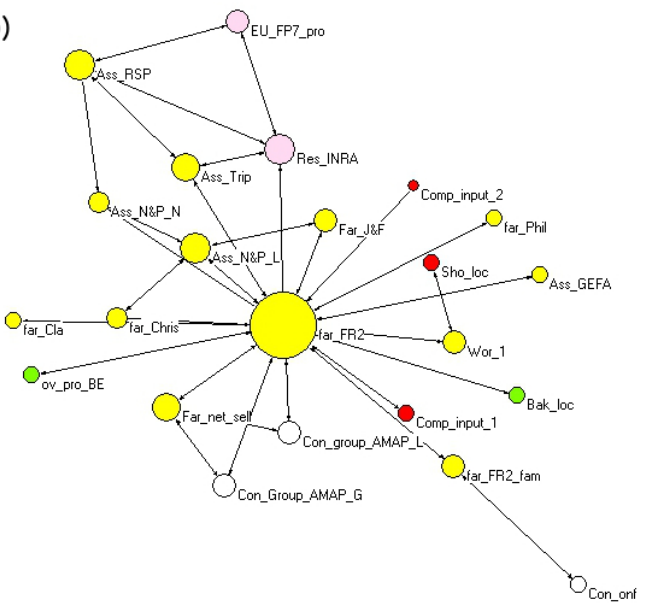

d)

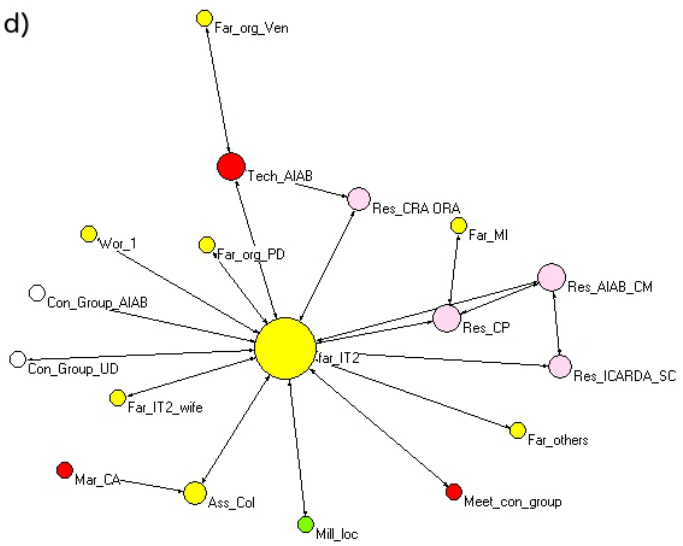

Figure 1. Farmers knowledge networks ( a) FR1 b) FR2 c) IT1 d) IT2 ) by number of connections and economic sectors (Agriculture (yellow), Processing industry (green), Services (red) Public Administration (blue), Research (pink) Households (white)). The size of the circle is related to the number of connections that each node has with others, while the lengths of the connections do not have any significance. The graphs are developed following an ego network analysis approach and using the program "Pajek". See Appendix for a complete list of actors.

Innovation activity is managed by the farmers with the direct participation of other actors such as researchers, farmers' associations, consumers etc. This structure of "collective management" of on-farm innovation that directly includes the spread of innovation in the process of innovation development itself is one of the most important characteristics of this transition pathway. These farmers work in close collaboration with individual researchers from public research institutions. The connection to a specific researcher is often followed by an exchange of material, in general seeds, with the researchers themselves or with other relevant actors. More than one person in the family is active in the farming system. Local administrators exchange knowledge with both IT1 and FR1 for the development of local projects with different aims: educational activities with schools, projects to close the cereal supply chain at a local level, projects to reproduce seeds of old traditional varieties etc. Concerning farmers' associations, FR1 and IT1 perceive several actors as relevant. Their membership of different farmers associations is in both cases connected to a strong participation and inclusive attitude. The influence on innovation development of such organisations is often related to the opportunity to meet with other farmers who have similar interests in different contexts. The peer to peer exchange is recognised as a good strategy to develop and spread innovation. In particular FR1 participated in three study trips to other countries (Spain, Syria, Germany), the latter of which has been followed by a direct contact with farmers and researchers from Germany not just for knowledge but also for seed exchange. IT1 included the contact with the French RSP (Reseau Semences Paysannes www.semencespaysannes.org) that he developed thanks to a study trip and an event that the Italian RSR (Rete Semi Rurali - www.semirurali.net) organized on his farm to meet with farmers and bakers from all over Europe.

At the same time, the farmers offer opportunities for exchanges among farmers on their own farms. The funding mechanisms through the EU to the regional administration and then to the farmers are well described by both subjects. IT1 is aware of the funding for Rural Development Plans because he used them to fund the building of his mill and on farm pasta processing plant. FR1 is more aware of the 
research funding mechanisms, because he was involved in research projects in collaboration with INRA. The vision of internal and external actors in terms of contribution to the functioning of the system is variable among the interviewed farmers. FR1 considered just himself, his family and the worker as internal to the system; FR2 defined six actors as internal and the rest as external. The internal actors could be divided into two groups, those who have more relationships with the external actors and those who have mainly internal relationships. IT2 includes consumers as actors internal to the system as "the system cannot function without them". IT1 considers all the actors and the link described as internal to the farm system, as in his vision they all contribute to its functioning.

\section{Discussion: Moving Through an Agroecological Innovation Paradigm}

The aim of this study was to explore an innovative approach to describe actors emerging in rural areas, following an agroecological approach to innovation in agriculture. Four case studies are not exhaustive, but the exercise shows promising results and it would be interesting to replicate it in other cases. Networks indicators such as centrality measures can be used for a more detailed analysis on the role of individual actors in the network. Looking at local learning capacity and systems of relations seems to give an effective contribution to understanding the potential to develop innovation within a specific context.

From the analysis of case studies, it emerged that the main relevant actors in knowledge exchange of farmers that represent innovation "best practice" are other farmers and farmers' associations together with consumers or citizens and individual publicly funded researchers. No role is given to extension services, which are otherwise often considered as key actors for innovation transfer by public policies. The advisors nominated by the farmers are independent with a high level of commitment to their work, and often have a key role in enlarging the individual farmers knowledge systems. The "transfer of technology" typical of a top-down linear process of innovation is not effective in the new context of sustainability $[20,44]$, which is characterised by complexity and uncertainty [45]. The role of technicians identified by the four farmers is more similar to that of innovation brokers. Moreover, the farmers investigated in the case studies are collaborating with public research agencies, which can play a pivotal role in promoting decentralised and participatory research [46]. This result confirms the need to give a completely new role to extension services to enhance knowledge sharing. The facilitator and/or innovation broker should be considered as intermediate actors enhancing AKIS at a local level. Advisors should be part of the network together with researchers, farmers, local institutions and all other stakeholders. In this framework, agricultural and rural innovation policies should promote the dynamic exchange of knowledge among peers as a training tool in agriculture, e.g. through funding visits to others with similar experiences in different regions or countries.

Another important aspect is related to public research systems. In a perspective of integral sustainability of agriculture it is crucial to maintain and increase public funds for agricultural research on organic and low-input farming systems and do more to strengthen the participation and decentralization of public research systems. However what is also important is to revise the evaluation system of public research institutions encouraging a Result Based Management approach [47] to agricultural research.

In fact, a trend that needs to be reversed in order to promote sustainability pathways based on the agro-ecological paradigm is the disincentive for researchers and institutions to be involved in AKIS and to contribute to the collective development of new knowledge. As stated by Wolf et al. "the Impact Factor and other journal-based metrics are increasingly considered inappropriate for comparing the scientific output of individuals and institutions" [48]. Furthermore, "innovation" is becoming a synonym for "patent" and has no relationship at all with the actual uptake of a solution by end-users, especially farmers. According to the agroecological approach to innovation, an excellent piece of research which is published in a high-ranked international scientific journal, but whose knowledge is not applied by the end users is not an innovation at all.

It is also worth noting that in the world of research there is a clear idiosyncrasy. On the one hand, the trend towards evaluation of researchers and institutions based on bibliographic indicators and patents (with clear consequences on fund allocation) is being strengthened [49]. On the other hand, major funders (e.g. the European Commission through the new Horizon 2020 framework programme) are advocating a multi-disciplinary, multi-actor approach in agricultural research. This means that stakeholders (actors) should be actively involved in research projects from the very beginning much more so than in the past rather than being passive recipients of disseminated project results. In agricultural research, this applies to farmers and their organisations, companies (including breeders) and other potential contributors to and end users of new knowledge generated in research projects. Following this pathway should guarantee that collaboration between researchers and multiple actors (including farmers) will be fully exploited for the mutual benefit of all partners engaged in a project and of society at large. The current approach of agricultural research evaluation denies the recent trends in research funding fostered by the EC and hence the importance of multi-actor collaboration (e.g. EIP AGRI experience). For the time being, there is little structural incentive for researchers or institutions to become engaged in participatory research because this part of their work is not considered a valuable research output. The consequence is that inter- and trans-disciplinary research, the basis for innovation in the agroecological sense, is discouraged [46]. Here, we are not downgrading the importance of producing excellent research publications and patents: we are simply claiming that considering these as the only valuable outputs of research is narrow-minded, will 
increase the gap between researchers, farmers and other end-users, and will jeopardize the production of innovation.

In order to reverse this trend the approach of research evaluation agencies should promptly incorporate new indicators valorising inter- and trans-disciplinary research. There are new developments on this subject [48], but "these are still confronted by incentive systems that favour the old style of evaluation and old method of producing research: mono-disciplinary, with a focus on publication in international journals" [49].

National and EU Agricultural policies which support novelties and bottom-up innovations with subsidies and niche market development, if integrated with innovation policies that encourage knowledge exchange using a multi-actor approach, could facilitate a more coherent scaling up of such innovations, as is already happening in some contexts. The possibility of scaling up innovations developed in a knowledge system with a network structure, in which different actors work side by side, can improve the likelihood of contributing at a micro level to radical changes in the systems required by a territorial approach to sustainability. This approach sees the creation of a network of best practices at a local level as the basis to attain sustainability goals at society level [50].

\section{References and Notes}

[1] Van der Ploeg JD. The new peasantries: struggles for autonomy and sustainability in an era of empire and globalization. Routledge; 2009.

[2] Woodhouse P. Beyond industrial agriculture? Some questions about farm size, productivity and sustainability. Journal of Agrarian Change. 2010;10(3):437-453. doi:10.1111/j.1471-0366.2010.00278.x

[3] Van der Ploeg JD, Renting H, Brunori G, Knickel K, Mannion J, Marsden T, et al. Rural Development: From Practices and Policies towards Theory. Sociologia Ruralis. 2000;40(4):391-408. doi:10.1111/14679523.00156.

[4] Bonnin I, Bonneuil C, Goffaux R, Montalent P, Goldringer I. Explaining the decrease in the genetic diversity of wheat in France over the 20th century. Agriculture, Ecosystems \& Environment. 2014;195:183-192. doi:10.1016/j.agee.2014.06.003.

[5] Malandrin V. Procesos participativos de innovacion agro-ecologica en el sector de los cereales orgánicos: el caso de estudio de la finca Pratini en Toscana, Italia. Sevilla, Spain: International University of Andalucia; 2012.

[6] Benayas JR, Martins A, Nicolau JM, Schulz JJ. Abandonment of agricultural land: an overview of drivers and consequences. CAB reviews: Perspectives in Agriculture, Veterinary Science, Nutrition and Natural Resources. 2007;2(57):1-14. doi:10.1079/PAVSNNR20072057.

[7] Barbier M, Elzen B, et al. System innovations, knowledge regimes, and design practices towards transitions for sustainable agriculture. INRA-Département Sciences pour l'Action et le Développement (SAD); 2012.

[8] Levidow L, Birch K, Papaioannou T. Divergent paradigms of European agro-food innovation: The knowledge-based bio-economy (KBBE) as an R\&D agenda. Science, Technology, \& Human Values. 2013;38(1):94-125. doi:10.1177/0162243912438143.

[9] Baumgärtner S, Quaas MF. Ecological-economic viability as a criterion of strong sustainability under uncertainty. Ecological Economics. 2009;68(7):2008-2020. doi:10.1016/j.ecolecon.2009.01.016.

[10] Buttel FH. Ideology and agricultural technology in the late twentieth century: Biotechnology as symbol and substance. Agriculture and Human Values. 1993;10(2):5-15. doi:10.1007/BF02217599.

[11] Pimbert MP. Towards food sovereignty: reclaiming autonomous food systems. International institute for environment and development (IIED), address=London, UK; 2008.

[12] Steyaert $P$, Jiggins J. Governance of complex environmental situations through social learning: a synthesis of SLIM's lessons for research, policy and practice. Environmental Science \& Policy. 2007;10(6):575-586. doi:10.1016/j.envsci.2007.01.011.

[13] van der Weijden W, Huber M, Jetten T, Blom P, Van Egmond N, Lauwers $\mathrm{L}$, et al. Towards an integral approach to sustainable agriculture and healthy nutrition: vision of the Scientific Council for Integral Sustainable Agriculture and Nutrition. The Netherlands: Scientific Council for Integral Sustainable Agriculture and Nutrition; 2012.

[14] Miller TR, Wiek A, Sarewitz D, Robinson J, Olsson L, Kriebel D, et al. The future of sustainability science: a solutions-oriented

research agenda. Sustainability Science. 2014;9(2):239-246. doi:10.1007/s11625-013-0224-6.

[15] Altieri MA. Agroecology: the science of natural resource management for poor farmers in marginal environments. Agriculture, Ecosystems \& Environment. 2002;93(1):1-24. doi:10.1016/S0167-8809(02)000853.

[16] Francis C, Lieblein G, Gliessman S, Breland T, Creamer N, Harwood R, et al. Agroecology: the ecology of food systems. Journal of Sustainable Agriculture. 2003;22(3):99-118. doi:10.1300/J064v22n03_10.

[17] Roep D, Wiskerke JS. On governance, embedding and marketing: reflections on the construction of alternative sustainable food networks. Journal of Agricultural and Environmental Ethics. 2012;25(2):205221. doi:10.1007/s10806-010-9286-y.

[18] Pfau SF, Hagens JE, Dankbaar B, Smits AJ. Visions of sustainability in bioeconomy research. Sustainability. 2014;6(3):1222-1249. doi:10.3390/su6031222.

[19] Arrow KJ. The Economic Implications of Learning by Doing. In: Hahn $\mathrm{FH}$, editor. Readings in the Theory of Growth. Springer; 1971. pp. 131-149.

[20] Knickel K, Brunori G, Rand S, Proost J. Towards a better conceptual framework for innovation processes in agriculture and rural development: From linear models to systemic approaches. Journal of Agricultural Education and Extension. 2009;15(2):131-146. doi:10.1080/13892240902909064

[21] Brunori G, Rand S, Proost J, Barjolle D, Granberg L, Dockes A. Towards a conceptual framework for agricultural and rural innovation policies. Frankfurtam a. Main, Germany: IN-SIGHT-Project; 2008.

[22] Leeuwis C. Communication for rural innovation: Rethinking agricultural extension. John Wiley \& Sons; 2013.

[23] Hall A. Public-private sector partnerships in an agricultural system of innovation: concepts and challenges. International Journal of Technology Management \& Sustainable Development. 2006;5(1):3-20. doi:10.1386/ijtm.5.1.3/1.

[24] Fonte M. Knowledge, food and place. A way of producing, a way of knowing. Sociologia Ruralis. 2008;48(3):200-222. doi:10.1111/j.1467-9523.2008.00462.x.

[25] Ceccarelli S, Bailey E, Tutwiler R. Decentralized participatory plant breeding: A link between formal plant breeding and small farmers. In: International Seminar on Participatory Research and Gender Analysis for Technology Developmnt. Cali, Colombia; 1996. pp. 65-74. Available from: cgspace.cgiar.org/bitstream/handle/10568/ 56460/S540.8.C4_N4_C3_International_seminar_on_participatory_ Research_and_Gender.pdf?sequence $=1 \#$ page $=66$.

[26] Chable V, Dawson J, Bocci R, Goldringer I. In: Bellon S, Penvern S editors. Seeds for organic agriculture: Development of participatory plant breeding and farmers' networks in france. Springer; 2014. pp. 383-400.

[27] Vanloqueren G, Baret PV. How agricultural research systems shape a technological regime that develops genetic engineering but locks out agroecological innovations. Research Policy. 2009;38(6):971-983. 
doi:10.1016/j.respol.2009.02.008

[28] Darnhofer I, Lindenthal T, Bartel-Kratochvil R, Zollitsch W. Conventionalisation of organic farming practices: from structural criteria towards an assessment based on organic principles. A review. Agronomy for Sustainable Development. 2010;30(1):67-81. doi:10.1051/agro/2009011.

[29] Ceccarelli S, Grando S, Maatougui M, Michael M, Slash M, Haghparast $\mathrm{R}$, et al. Plant breeding and climate changes. The Journal of Agricultural Science. 2010;148(06):627-637. doi:10.1017/S0021859610000651.

[30] Ceccarelli S, Grando S, Amri A, Asaad F, Benbelkacem A, Harrabi M, et al. Decentralized and participatory plant breeding for marginal environments. In: Cooper HD, Spillane C, Hodgkin T, editors. Broadening the genetic base of crop production. Rome, Italy: CAB International, IPGRI and FAO; 2001. pp. 115-135.

[31] Ceccarelli S, Grando S. Decentralized-participatory plant breeding: an example of demand driven research. Euphytica. 2007;155(3):349360. doi:10.1007/s10681-006-9336-8.

[32] Ceccarelli S. Decentralized-Participatory Plant Breeding: Lessons from the South-Perspectives in the North. In: Desclaux D, Hédont $M$, editors. Proceedings of the ECO-PB Workshop : "Participatory Plant Breeding: Relevance for Organic Agriculture?". La Besse, France; 2006. pp. 8-17. Available from: selection-participative.cirad. $\mathrm{fr} /$ content/download/832/4129/file/ECOPB.pdf\#page =8.

[33] Ceccarelli S. Efficiency of Plant Breeding. Crop Science. 2015;55:8797. doi:10.2135/cropsci2014.02.0158.

[34] Wasserman S, Faust K. Social network analysis: Methods and applications. Vol. 8. Cambridge, UK: Cambridge University Press; 1994.

[35] Burt RS. Social contagion and innovation: Cohesion versus structural equivalence. American Journal of Sociology. 1987;92(6):1287-1335. doi:10.1086/228667.

[36] Granovetter M. The strength of weak ties. American Journal of Sociology. 1973;78(6):1360-1380. doi:10.1086/225469.

[37] Granovetter M. Economic action and social structure: The problem of embeddedness. American Journal of Sociology. 1985;91(3):481-510. doi:10.1086/228311.

[38] Borgatti SP, Mehra A, Brass DJ, Labianca G. Network analysis in the social sciences. Science. 2009;323(5916):892-895. doi:10.1126/science.1165821.

[39] Vanwindekens FM, Stilmant D, Baret PV. Development of a broadened cognitive mapping approach for analysing systems of practices in social-ecological systems. Ecological Modelling. 2013;250:352362. doi:10.1016/j.ecolmodel.2012.11.023.

[40] Rey F, Bocci R, Cable V, editors. 10 SOLIBAM key innovations - Cultivating diversity. Strategies for Organic and Low-input Integrated Breeding and Management Collaborative Project; 2014 Available from: http://www.itab.asso.fr/downloads/solibam/solibam innovations-eng.pdf.

[41] Wilson GA. From 'weak' to 'strong' multifunctionality: conceptualising farm-level multifunctional transitional pathways. Journal of Rural Studies. 2008;24(3):367-383. doi:10.1016/j.jrurstud.2007.12.010.

[42] Newig J, Gaube V, Berkhoff K, Kaldrack K, Kastens B, Lutz J, et al. The role of formalisation, participation and context in the success of public involvement mechanisms in resource management. Systemic Practice and Action Research. 2008;21(6):423-441. doi:10.1007/s11213-008-9113-9.

[43] Bassi I, Zaccarin S, De Stefano D. Rural inter-firm networks as basis for multifunctional local system development: Evidence from an Italian alpine area. Land Use Policy. 2014;38:70-79. doi:10.1016/j.landusepol.2013.10.021.

[44] Röling N. Pathways for impact: scientists' different perspectives on agricultural innovation. International journal of agricultural sustainability. 2009;7(2):83-94. doi:10.3763/ijas.2009.0043.

[45] Waltner-Toews D, Kay JJ, Lister NME. The ecosystem approach: complexity, uncertainty, and managing for sustainability. New York, NY, USA: Columbia University Press; 2008.

[46] Rey F, Bocci R, Cable V, editors. Policy recommendations to sustain diversity strategies within food systems. Strategies for Organic and Low-input Integrated Breeding and Management Collaborative Project; 2014. Available from: http://www.solibam.eu/modules/ wfdownloads/visit.php?cid=3\&lid=56.

[47] Results-based Management Handbook. United Nations Development Group; 2012. Available from: http://www.undg.org/docs/12316/ UNDG-RBM\%20Handbook-2012.pdf.

[48] Wolf BM, Häring AM, Heß J. Strategies towards evaluation beyond scientific impact. Pathways not only for agricultural research. Organic Farming. 2015;1(1):3-18. doi:10.12924/of2015.01010003.

[49] Spaapen JB, et al. A new evaluation culture is inevitable. Organic Farming. 2015;1(1):36-37. doi:10.12924/of2015.01010036.

[50] Wilkinson J. The Mingling of Markets, Movements \& Menus. In: International Workshop: Globalization, Social and Cultural Dynamics. Rio de Janeiro, RJ, Brazil; 2006. 
Table A1. IT1

\begin{tabular}{|c|c|c|c|}
\hline & Code I & Label & Actor \\
\hline IT1 & 1 & far_mul & farmers \\
\hline IT1 & 2 & far_soc & farmers \\
\hline IT1 & 3 & Bak_alt & retail outlets \\
\hline IT1 & 4 & Tech_GP & consultants \\
\hline IT1 & 5 & Res_ProfSB & knowledge institutes and researchers \\
\hline IT1 & 6 & Tec_MB & consultants \\
\hline IT1 & 7 & Ass_Bdyn & NGOs \\
\hline IT1 & 8 & Res_RB & consultants \\
\hline IT1 & 9 & Doc_Onc & knowledge institutes and researchers \\
\hline IT1 & 10 & Res_ProfGB & knowledge institutes and researchers \\
\hline IT1 & $11-$ & Tech_C & consultants \\
\hline IT1 & 12 & Cit_health & customers \\
\hline IT1 & 13 & Tech_CP & consultants \\
\hline IT1 & 14 & Act_com & retail outlets \\
\hline IT1 & 15 & PA_Mun_PT & farmersfarmers \\
\hline IT1 & 16 & Ass_RSR & NGOs \\
\hline IT1 & $17 f$ & far_Bdyn & farmers \\
\hline IT1 & 18 & Ass_CTPB & cooperation at local and extralocal level \\
\hline IT1 & 19 & Com_DR & suppliers \\
\hline IT1 & 20 & DES_PI & customers \\
\hline IT1 & 21 & PA_EU & political institution \\
\hline IT1 & 22 & Con_fam & customers \\
\hline IT1 & $23 f$ & far_IT1 & farmers \\
\hline IT1 & $24 f$ & far_IT1_bro & farmers \\
\hline IT1 & $25 f$ & far_IT1_wife & farmers \\
\hline IT1 & 26 & Far_meet & cooperation at local and extralocal level \\
\hline IT1 & 27 & Bak_flo & retail outlets \\
\hline IT1 & 28 & Res_RF & consultants \\
\hline IT1 & 29 & Con_Groups & customers \\
\hline IT1 & 301 & Agr_Nut & consultants \\
\hline IT1 & 31 & Ev_Fr_far & cooperation at local and extralocal level \\
\hline IT1 & 32 & Ev_br_08 & cooperation at local and extralocal level \\
\hline IT1 & 33 & Bak_Mad & retail outlets \\
\hline IT1 & 34 & Coop_ster & cooperation at local and extralocal level \\
\hline IT1 & 35 & Comp_mach & suppliers \\
\hline IT1 & 36 & Res_PM & knowledge institutes and researchers \\
\hline IT1 & 371 & Mill_MS & processing industries \\
\hline IT1 & 38 & Onf_Sho_PT & retail outlets \\
\hline IT1 & $39 f$ & far_N_15 & farmers \\
\hline
\end{tabular}


Table A2: Cont.

\begin{tabular}{llll}
\hline \multicolumn{2}{c}{ Code } & Label & Actor \\
\hline IT1 & 40 & far_N_20 & farmers \\
IT1 & 41 & far_N_50 & farmers \\
IT1 & 42 & On_sho_IT1 & retail outlets \\
IT1 & 43 & Far_others & farmers \\
IT1 & 44 & Doc_PR & knowledge institutes and researchers \\
IT1 & 45 & Schools & education \\
IT1 & 46 & Cons_pr & customers \\
IT1 & 47 & Pro_old_mill & processing industries \\
IT1 & 48 & PA_Pro_PI & political institution \\
IT1 & 49 & RDP_06 & processing industries \\
IT1 & 50 & RDP_10_Mill & processing industries \\
IT1 & 51 & RDP_11_Pasta & processing industries \\
IT1 & 52 & PA_Reg_Tus & political institution \\
IT1 & 53 & Cus_Rest & retail outlets \\
IT1 & 54 & Far_net_sell & farmers \\
IT1 & 55 & Ass_RSP & NGOs \\
IT1 & 56 & Cus_Org_Sho & retail outlets \\
IT1 & 57 & Res_UNIFI & knowledge institutes and researchers \\
IT1 & 58 & Res_UNIPI & knowledge institutes and researchers \\
IT1 & 59 & Wor_1 & suppliers \\
IT1 & 60 & Far_IT1_Mot & farmers \\
IT1 & 61 & Loc_Bank & financial service providers \\
IT1 & 62 & Website & communication \\
IT1 & 63 & Comp_Pack & suppliers \\
IT1 & 64 & BC_proc & processing industries \\
IT1 & 65 & BC_Agr & farmers \\
IT1 & 66 & Wor_5 & suppliers \\
IT1 & 67 & PA_Mun_Semp & political institution \\
IT1 & 68 & Wor_2 & suppliers \\
IT1 & 69 & Wor_3 & suppliers \\
IT1 & 70 & Wor_4 & suppliers \\
\hline
\end{tabular}


Table A3. IT2

\begin{tabular}{|c|c|c|c|}
\hline & Code & Label & Actor \\
\hline IT2 & 1 & far_IT2 & Farmer IT2 \\
\hline IT2 & 2 & Tech_AIAB & AIAB Technician \\
\hline IT2 & 3 & Res_CP & Researcher from ER Region CP \\
\hline IT2 & 4 & Res_AIAB_CM & AIAB Researcher CM \\
\hline IT2 & 5 & Ass_Col & Association Coldiretti \\
\hline IT2 & 6 & Res_CRA ORA & Researcher Agricultural Research Council (CRA ORA) \\
\hline IT2 & 7 & Far_others & Other Farmers \\
\hline IT2 & 8 & Far_org_PD & Organic farmer in PD \\
\hline IT2 & 9 & Wor_1 & Worker \\
\hline IT2 & 10 & Far_IT2_wife & Farmer IT2 wife \\
\hline IT2 & 11 & Con_Group_UD & Consumers'group in UD \\
\hline IT2 & 12 & Con_Group_AIAB & Consumers'group AIAB \\
\hline IT2 & 13 & Meet_con_group & Meetings with consumers' group \\
\hline IT2 & 14 & Mill_loc & Local miller \\
\hline IT2 & 15 & Res_ICARDA_SC & Researcher ICARDA Ceccarelli \\
\hline IT2 & 16 & Far_org_Ven & Organic farmers in Veneto \\
\hline IT2 & 17 & Far_Ml & Farmer in Milan Province \\
\hline IT2 & 18 & Mar_CA & Farmers Market "Campagna Amica" \\
\hline IT2 & 19 & Comp_input_loc & Local input provider company \\
\hline IT2 & 20 & Cons & Consumers \\
\hline
\end{tabular}


Table A4. FR1

\begin{tabular}{|c|c|c|c|}
\hline & Code & Label & Actor \\
\hline FR1 & 1 & far_FR1 & Farmer FR1 \\
\hline FR1 & 2 & far_FR1_mo & Farmer FR1 Mother \\
\hline FR1 & 3 & far_FR1_fath & Farmer FR1 Father \\
\hline FR1 & 4 & far_FR1_bro & Farmer FR1 Brother \\
\hline FR1 & 5 & Stag_FR1 & Stagiers \\
\hline FR1 & 6 & Wor_1 & Worker \\
\hline FR1 & 7 & Tech_ITAB & Istitut technique de l'Agriculture Biologique - ITAB \\
\hline FR1 & 8 & Ass_FNAB & Federation Nationale d'Agriculture Biologique - FNAB \\
\hline FR1 & 9 & PA_Mun & Local Municipality \\
\hline FR1 & 10 & Con_Group & Consumers Group - AMAP \\
\hline FR1 & 11 & Ev_onf_vis & Visits on farm \\
\hline FR1 & 12 & Mar_loc & Farmers Market \\
\hline FR1 & 13 & Con_onf & Consumers on farm \\
\hline FR1 & 14 & Comp_seeds & Commercial seeds company \\
\hline FR1 & 15 & Far_Neig & Neighbour Farmers \\
\hline FR1 & 16 & Ass_FB & Association Formation blè \\
\hline FR1 & 17 & Ass_GAB & Groupement des Agriculterurs Biologique - GAB \\
\hline FR1 & 18 & Ass_Trip & Association Triptoleme \\
\hline FR1 & 19 & Ass_RSP & Reseau Semences Paysannes - RSP \\
\hline FR1 & 20 & Res_INRA & Institut National de la Recherche Agronomique - INRA \\
\hline FR1 & 21 & St_tr_ES & Study trip in Spain \\
\hline FR1 & 22 & Far_D & Farmers from germany \\
\hline FR1 & 23 & Vol_wor_con & Events of voluntary work for consumers \\
\hline FR1 & 24 & Vol_wor_seed & Events of voluntary work for seeds \\
\hline FR1 & 25 & Far_CUMA & Farmers from Coopératives d'Utilisation de Matériel Agricole - CUMA \\
\hline FR1 & 26 & Cus_Org_Sho & Organic Shop \\
\hline FR1 & 27 & PA_Reg & Regional Administration \\
\hline FR1 & 28 & Pr_Found & Private Foundations \\
\hline FR1 & 29 & PA_EU & European Union \\
\hline FR1 & 30 & St_tr_D & Study trip in Germany \\
\hline FR1 & 31 & Res_D & Researchers from Germany \\
\hline FR1 & 32 & St_tr_ES & Study trip in Syria \\
\hline
\end{tabular}


Table A5. FR2

\begin{tabular}{lcll}
\hline \multicolumn{2}{c}{ Code } & Label & Actor \\
\hline FR2 & 1 & far_Chris & Farmer Christopher \\
FR2 & 2 & Ass_N\&P_N & Association "Nature et progres" - National group \\
FR2 & 3 & far_Phil & Farmer Philippe \\
FR2 & 4 & Wor_1 & Worker \\
FR2 & 5 & Comp_input_1 & Local input provider company - VEGAM \\
FR2 & 6 & Ass_Trip & Association Triptoleme \\
FR2 & 7 & EU_FP7_pro & EU FP7 Project SOLIBAM \\
FR2 & 8 & Far_J\&F & Farmers Julie et Florent \\
FR2 & 9 & Res_INRA & Institut National de la Recherche Agronomique - INRA \\
FR2 & 10 & Ass_GEFA & Group for collective land purchase - GEFA \\
FR2 & 11 & far_FR2_fam & Farmer FR2 Family \\
FR2 & 12 & Sho_loc & Local grocery shop \\
FR2 & 13 & far_FR2 & Farmer FR2 \\
FR2 & 14 & Con_onf & Consumers on farm \\
FR2 & 15 & far_Cla & Farmer Claude \\
FR2 & 16 & ov_pro_BE & Oven provider from Belgium \\
FR2 & 17 & Bak_loc & Baker \\
FR2 & 18 & Con_group_AMAP_L & Consumers group AMAP - L \\
FR2 & 19 & Con_Group_AMAP_G & Consumers group AMAP - G \\
FR2 & 20 & Far_net_sell & Network of 4 farmers for selling \\
FR2 & 21 & Ass_RSP & Reseau Semences Paysannes - RSP \\
FR2 & 22 & Ass_N\&P_L & Association "Nature et progres" - local group \\
FR2 & 23 & Comp_input_2 & Local input provider company - PINAILT SA \\
FR2 & 24 & Coop_Org_Sho & Organic shop - BIOCOOP \\
FR2 & 25 & Comp_input_3 & Local input provider company - APROBIO \\
FR2 & 26 & Coop_CUMA & Coopératives d'Utilisation de Matériel Agricole - CUMA \\
FR2 & 27 & Org_cert_body & Organic certification body \\
FR2 & 28 & PA_DDTM & Agency for public funds - DDTM \\
\hline & & & \\
& &
\end{tabular}

